\title{
Analisis Hubungan Kemampuan Manajemen Konflik Kepala Ruangan dengan Kepuasan Kerja Perawat Pelaksana di Ruang Rawat Inap Rumah Sakit Tk. III Reksodiwiryo Padang
}

\author{
Astri Doris ${ }^{1}$, Fatma Sriwahyuni ${ }^{2}$, Vetty Priscilla $^{3}$ \\ ${ }^{1}$ Magister Keperawatan, Fakultas Keperawatan, Universitas Andalas, Padang, 25163,Indonesia \\ ${ }^{2}$ Fakultas Farmasi, Universitas Andalas, Padang, 25163,Indonesia \\ ${ }^{3}$ Fakultas Keperawatan, Universitas Andalas, Padang, 25163, Indonesia \\ e-mail korespondensi : astridoris20@gmail.com
}

\begin{abstract}
Some negative impacts that can be caused by conflicts include the decrease of work productivity, such as affecting teamwork relationships that have an impact on job satisfaction of implementing nurses, and the process of service activities undertaken is hampered. The purpose of this study was to analyze the relationship between conflict management of the head nurse of the room with the work satisfaction of implementing nurses. This type of research is quantitative research with cross sectional approach. The sampling technique was proportional random sampling with a sample size of 83 people. The results of the study were obtained. There is a significant relationship between conflict management and job satisfaction at Tk III Dr.Reksodiwiryo Hospital ( $p$-value 0,000 <0.05), compromise strategy $(p=0.017)$, competency strategy $(p=0.025)$, accommodation strategy $(p=$ $0,000)$, avoidance strategy (0.017), collaboration strategy $(p=0.021)$. It is expected that nurses will improve communication within the team and the hospital to be concerned about efforts to improve employee performance satisfaction.
\end{abstract}

Keywords: Conflict Management, Work Satisfaction Nurses

\section{Abstrak}

Dampak negatif yang dapat ditimbulkan oleh konflik antara lain menurunnya produktivitas kerja, seperti mempengaruhi hubungan kerja tim sehingga berdampak pada kepuasan kerja perawat pelaksana, dan proses kegiatan pelayanan yang dilakukan menjadi terhambat. Tujuan dari penelitian ini adalah untuk menganalisis hubungan manajemen konflik kepala ruangan dengan kepuasan kerja perawat pelaksana. Jenis penelitian ini adalah penelitian kuantitatif dengan pendekatan cross sectional. Teknik pengambilan sampel dengan proportional random sampling dengan jumlah sampel 83 orang. Hasil penelitian didapatkan bahwa terdapat hubungan yang bermakna antara manajemen konflik dengan kepuasan kerja di RS Tk III Dr.Reksodiwiryo ( $p$-value 0,000<0,05), strategi kompromi $(\mathrm{p}=0,017)$, strategi kompetensi $(\mathrm{p}=0,025)$, strategi akomodasi $(\mathrm{p}=0,000)$, startegi menghindar $(0,017)$, strategi kolaborasi $(\mathrm{p}=0,021)$. Diharapkan kepada perawat untuk menigkatkan komuniasi dalam tim dan kepada pihak rumah sakit agar peduli dalam usaha peningkatan kepuasan kinerja pegawai.

Kata Kunci : Manajemen Konflik, Kepuasan Kerja,Perawat Pelaksana

\section{PENDAHULUAN}

Pelayanan keperawatan merupakan bagian dari pelayanan kesehatan di rumah sakit yang dituntut untuk memberikan pelayanan yang berkualitas. Kualitas layanan kesehatan yang bermutu hanya dapat dihasilkan oleh sumber daya manusia yang berkualitas. Untuk itu diperlukan sistem manajerial keperawatan yang tepat untuk mengarahkan seluruh sumber daya keperawatan dalam menghasilkan pelayanan keperawatan yang prima dan berkualitas.

Individu-individu maupun kelompok dalam suatu organisasi akan saling bergantung satu sama lain dalam hal 
informasi, bantuan ataupun tindakan terkoordinasi untuk menciptakan hubungan kerja yang efektif. Ketergantungan seperti ini dapat meningkatkan kerjasama maupun konflik

Manajemen konflik termasuk pada suatu strategi yang berorientasi pada proses yang mengarahkan pada bentuk komunikasi (termasuk tingkah laku) dari pelaku maupun pihak luar dan bagaimana mereka mempengaruhi kepentingan (interests) dan interpretasi. Bagi pihak luar (di luar yang berkonflik) sebagai pihak ketiga, yang diperlukannya adalah informasi yang akurat tentang situasi konflik. Hal ini karena komunikasi efektif di antara pelaku dapat terjadi jika ada kepercayaan terhadap pihak ketiga (Khayati, 2013).

Konflik secara umum didefinisikan sebagai perselisihan internal atau eksternal akibat adanya perbedaan gagasan, nilai atau perasaan antara dua orang atau lebih. Karena setiap individu memiliki hubungan interpersonal dengan orang lain yang memiliki nilai, keyakinan, latar belakang dan tujuan yang berbeda, maka konflik merupakan hal yang telah diperkirakan akan terjadi.

Konflik dapat menimbulkan dampak positif maupun dampak negatif dalam setiap organisasi, tergantung seberapa sering konflik tersebut terjadi dan bagaimana konflik tersebut dikelola Konflik yang menimbulkan dampak positif bagi kelompok atau organisasi yang bersangkutan bersifat konstruktif. Sebaliknya, konflik yang menimbulkan dampak negatif bagi kelompok atau organisasi yang bersangkutan bersifat destruktif.

Berdasarkan penelitian Rachman, Hamzah \&Jafar yang dilakukan pada tahun 2013 tentang pengaruh perilaku kelompok terhadap kepuasan kerja perawat di RSUD Syekh Yusuf Kabupaten Gowa didapatkan hasil bahwa konflik merupakan salah satu variabel perilaku kelompok yang memiliki pengaruh terhadap kepuasan kerja perawat (Rachman, Hamzah \& Jafar, 2013).
Berdasarkan penelitian Rachman, Hamzah \&Jafar (2013) tentang pengaruh perilaku kelompok terhadap kepuasan kerja perawat di RSUD Syekh Yusuf Kabupaten Gowa didapatkan hasil bahwa konflik merupakan salah satu variabel perilaku kelompok yang memiliki pengaruh terhadap kepuasan kerja perawat

Berdasarkan penelitian yang sama dilakukan oleh Daniyanti (2016) didapatkan nilai $p$-value $=0,032$. Dari 40 perawat yang manajemen konfliknya baik, $(55,0 \%)$ perawat merasa puas dengan pekerjaannya. Sedangkan dari 33 perawat yang manajemen konfliknya kurang baik, $(72,3 \%)$ perawat merasa kurang puas dengan pekerjaannya. Sehingga dapat disimpulkan bahwa manajemen konflik memberikan pengaruh yang signifikan terhadap kepuasan kerja perawat.

Penelitian yang dilakukan Hamdan, Nussera, Masa'deh, Rami (2015) dengan hasil bahwa beberapa karakteristik demografi seperti kewarganegaraan, level manajer, senioritas, tingkat pendidikan, dan jenis kelamin berpengaruh secara signifikan terhadap pemilihan strategi manajemen konflik

Rumah Sakit Tingkat III Dr. Reksodiwiryo Padang merupakan Rumah Sakit pemerintah yang dikelola oleh TNI AD yang merupakan salah satu Rumah Sakit rujukan di Provinsi Sumatera Barat dan sudah terakreditasi. Rumah sakit ini terdiri dari instalasi rawat inap, instalasi rawat jalan dan instalasi gawat darurat (IGD). Rumah Sakit ini sudah memiliki delapan unit ruang rawat inap yang terdiri dari Ruang I, Ruang II, Ruang III, Ruang IV dan V, Ruang Ruang paru, Ruang Paviliun HWS, Ruang HCU dan Ruang Kebidanan, dengan total tempat tidur 202. Tenaga perawat di Rumah Sakit Tk. III Dr.Reksodiwiryo Padang seluruhnya berjumlah 175 orang dengan latar belakang pendidikan D3 dan S1 Keperawatan. Distribusi tenaga perawat menyebar di Instalasi rawat inap 24 jam, Instalasi rawat jalan dan Poli (Rekam 
MediK RS.Tk.III Dr. Reksodiwiryo Padang, 2016).

Berdasarkan hasil wawancara dengan tujuh orang perawat pada bulan februari 2018 di ruang rawat inap Rumah Sakit Tk.III.Dr.Reksodiwiryo padang berkaitan dengan konflik perawat mengatakan pasti ada dan pernah mangalamai konflik yang disebabkan karena berbagai hal antara lain salah komunikasi atau salah persepsi sesama teman, masalah pekerjaan di ruangan, masalah pembagian jadwal dinas dan pembagian jabatan diruangan seperti pemelihan Kepala Tim dan Perawat Pelaksana, rekan kerja yang malas melakukan pekerjaan, beban pekerjaan yang banyak diruangan, ketidak cocokan sesama tim dinas akibatnya terjadi percecokan sehingga menimbulkan suasana kerja yang tidak solid. Hasil observasi selama satu minggu pada bulan februari 2018 bahwa masing-masing diruangan memang pernah mengalami konflik, namun konflik yang muncul ditimbulkan antara teman di ruangan dengan masalah yang berbagai macam, ada masalah pekerjaan dimana teman atau rekan kerja yang malas dalam bekerja, salah komunikasi, dan kecemburuan sosial.

Terkait dengan kepuasan kerja empat orang perawat mengatakan ada yang merasa puas dengan pekerjaannya dan ada yang mengatakan belum puas dengan pekerjaannya dan ada mengatakan senang dengan pekerjaanya dan ada mengatakan malas bekerja kerena satu dinas dengan teman yang tidak di sukainya, terjadi kecemburuan sosial bahwa tidak puas dengan penerimaan jasa insentiv yaitu jasa BPJS di ruangannya, karena di dalam satu ruangan yang sama berbeda-beda mendapatkan insentiv, terkadang perawat yang baru masuk malah lebih besar pendapatan jasanya dari pada perawat yang lama sehingga menimbulkan kecemburuan sesama teman diruangan tersebut, lain halnya di ruangan yang berbeda kalo masalah perbedaan insentiv tidak apa-apa dan tidak masalah karena dimasing-masing ruangan memang mendapatkan jasa yang berbeda-beda, untuk penggajian perawat mengatakan belum merasa puas karena tidak sesuai tanggungan pekerjaan dan tanggung jawab yang dilakukan diruangan, tidak puas dengan tuntutan rumah sakit dengan peraturan-peraturan yang disiplinnya tinggi yang setiap hari harus wajib mengikuti apel pagi, ditambah dengan latihan PBB setelah melaksanakan Apel

Berdasarkan fenomena di atas maka peneliti tertarik untuk melakukan penelitian tentang analisis hubungan manajemen konflik kepala ruangan dengan kepuasan kerja perawat pelaksana di ruang rawat inap Rumah Sakit Tk.III.Dr. Reksodiwiryo padang tahun 2017.

\section{METODE}

Penelitian ini adalah penelitian kuantitatif, pengambilan sampel diambil secara proporsional simple random sampling yaitu dari 105 populasi didapatkan sampel sebanyak 83 responden.

Penelitian ini dilaksanakan di Rumah Sakit TK.III Reksodiwiryo Padang yaitu diruang rawat inap yang terdiri dari ruang I, ruang II, ruang III, ruang IV ruang $\mathrm{V}$, ruang paru, Ruang paviliun, ruang $\mathrm{HCU}$ dan HWS pada bulan Mei s/d Juni 2018.

Data diperoleh dengan melakukan pengisian kuesioner yang terdiri dari kuesioner karakteristik perawat, kuesioner untuk mengetahui strategi manajemen konflik. Adapun komposisi dari masingmasing komponen antara lain: kompromi, kompetisi, akomodasi, menghindar, kolaborasi kuesioner $\mathrm{C}$ tentang kepuasan kerja perawat.

Insrumen sudah dilakukan uji Validitas r-tabel > r Hitung yaitu sebesar 0,361 dan Cronbach"s Alpha sebesar 0,918. Analisis data dilakukan dengan dua cara yaitu dengan analisis Univariat dan analisis Bivariat. 
HASIL

Hasil penelitian menunjukan karakteristik perawat yang meliputi Umur, jenis kelamin, masa kerja, tingkat pendidikan yang dapat dilihat pada tabel 1.

\section{Tabel 1. Data Karakteristik}

\section{Responden}

\begin{tabular}{lcc}
\hline Karakteristik & $f$ & $\%$ \\
\hline Umur & & \\
< 28Tahun & 43 & 51,8 \\
$\geq 28$ Tahun & 40 & 48,2 \\
& & \\
\hline Jenis Kelamin & & \\
Wanita & 67 & 80,7 \\
Pria & 16 & 19,3 \\
\hline Masa Kerja & & \\
$<3$ Tahun & 66 & 79,5 \\
$\geq 3$ Tahun & 17 & 20,5 \\
\hline Tingkat Pendidikan & & \\
D3 & 68 & 81,9 \\
S1 & 15 & 18,1 \\
\hline
\end{tabular}

\section{Analisis Univariat}

Tabel 2. Distribusi Frekuensi Kepuasan

\section{Kerja}

\begin{tabular}{lcc}
\hline $\begin{array}{c}\text { Kepuasan } \\
\text { Kerja }\end{array}$ & $f$ & $\%$ \\
\hline Kurang Puas & 32 & 38,6 \\
Puas & 51 & 61,4 \\
\hline & $\mathbf{8 3}$ & $\mathbf{1 0 0}$ \\
\hline
\end{tabular}

Berdasarkan tabel 2 terlihat bahwa sebanyak $61,4 \%$ responden puas dalam kepuasan kerja.

Tabel 3. Distribusi Frekuensi Manajemen Konflik

\begin{tabular}{lcc}
\hline $\begin{array}{c}\text { Manajemen } \\
\text { Konflik }\end{array}$ & $f$ & $\%$ \\
\hline Lemah & 41 & 49,4 \\
Kuat & 42 & 50,6 \\
\hline & $\mathbf{8 3}$ & $\mathbf{1 0 0}$ \\
\hline
\end{tabular}

Berdasarkan tabel 3 terlihat bahwa sebanyak $50.6 \%$ perawat masuk dalam kaegori kuat utukmanajemen konflik. Dari hasil tabel tabel diatas memperlihatkan bahwa dari 85 perawat pelaksana merasa kurang puas dalam bekerja sebanyak $61,4 \%$ dan merasa puas dalam bekerja dan sebanyak $50,6 \%$ perawat masuk dalam kaegori kuat untuk manajemen konflik.

\section{Analisis Bivariat}

Hasil analisis bivariat dilakukanuntuk meliat hubungan serta statistik antara variabel dependendan independen sebagai berikut :

\section{Tabel 4. Hubungan Manajemen Konflik} dengan Kepuasan Kerja

\begin{tabular}{lccccccc}
\hline \multirow{2}{*}{$\begin{array}{c}\text { Manaje } \\
\text { men } \\
\text { Konflik }\end{array}$} & \multicolumn{3}{c}{ Kepuasan Kerja Perawat Pelaksana } & $\begin{array}{c}\mathrm{p}- \\
\text { Value }\end{array}$ \\
\cline { 2 - 7 } & $\begin{array}{c}\text { Kurang } \\
\text { Puas }\end{array}$ & \multicolumn{2}{c}{ Puas } & Total & \\
\cline { 2 - 7 } & $f$ & $\%$ & $f$ & $\%$ & $f$ & $\%$ & \\
\hline Lemah & 25 & 61,0 & 16 & 39,0 & 41 & 100 & 0,000 \\
Kuat & 7 & 16,7 & 35 & 83,3 & 42 & 100 & \\
\hline Jumlah & 32 & 38,6 & 51 & 61,4 & 83 & 100 & \\
& & & & & & &
\end{tabular}

Tabel 4 menunjukan bahwa hubungan kemampuan manajemen konflik dengan Kepuasan Kerja bahwa dari 41 responden yang memiliki kemampuan manjemen konflik lemah dengan kepuasan kerja yang kurang puas sebanyak $61,0 \%$. Sedangkan dari 42 responden dengan manajemen konflik kuat sebanyak $16,7 \%$. Hasil analisis ini juga didapatkan $p$ value 0,000 ( $\mathrm{p}$ value <0,05), ada hubungan yang bermakna antara hubungan kemampuan manajemen konflik dengan kepuasan kerja. 
Tabel 5. Hubungan Strategi Kompromi dengan Kepuasan Kerja

\begin{tabular}{lccccccc}
\hline \multirow{2}{*}{$\begin{array}{l}\text { Strategi } \\
\text { Kompro } \\
\text { mi }\end{array}$} & \multicolumn{2}{c}{$\begin{array}{c}\text { Kurang } \\
\text { Puas }\end{array}$} & \multicolumn{2}{c}{ Puas } & \multicolumn{2}{c}{ Total } & \\
\cline { 2 - 7 } & $f$ & $\%$ & $f$ & $\%$ & $f$ & $\%$ & \\
\hline Lemah & 18 & 56,3 & 14 & 43,8 & 32 & 100 & \\
Kuat & 14 & 27,5 & 37 & 72,5 & 51 & 100 & 0,017 \\
\hline Jumlah & 32 & 38,6 & 51 & 61,4 & 83 & 100 & \\
\hline
\end{tabular}

Tabel 5 menunjukan bahwa dari 32 responden yang memiliki strategi kompromi lemah dengan kepuasan kerja yang kurang puas sebanyak sebanyak $56,3 \%$. Sedangkan dari 51 responden dengan strategi yang kuat sebanyak $27,5 \%$. Hasil analisis ini juga didapatkan $p$ value 0,017 ( $\mathrm{p}$ value $<0,05$ ), ada hubungan yang bermakna antara strategi kompromi dengan kepuasan kerja.

\section{Tabel 6. Hubungan strategi Kompetisi dengan Kepuasan Kerja}

\begin{tabular}{lccccccc}
\hline \multirow{2}{*}{$\begin{array}{c}\text { Kompe } \\
\text { tisi }\end{array}$} & \multicolumn{3}{c}{ Kepuasan Kerja Perawat Pelaksana } & $\begin{array}{c}\mathrm{P} \\
\text { value }\end{array}$ \\
\cline { 2 - 8 } & \multicolumn{2}{c}{$\begin{array}{c}\text { Kurang } \\
\text { Puas }\end{array}$} & \multicolumn{2}{c}{ Puas } & \multicolumn{2}{c}{ Total } & \\
\cline { 2 - 8 } & $f$ & $\%$ & $f$ & $\%$ & $f$ & $\%$ & \\
\hline Lemah & 16 & 57,1 & 12 & 42,9 & 28 & 100 & \\
Kuat & 16 & 29,1 & 39 & 70,9 & 55 & 100 & 0,025 \\
\hline Jumlah & 32 & 38,6 & 51 & 61,4 & 83 & 100 & \\
\end{tabular}

Berdasarkan tabel 5.6 di atas didapatkan bahwa dari 28 responden yang memiliki strategi kompetisi lemah dengan kepuasan kerja yang kurang puas sebanyak $57,1 \%$. Sedangkan dari 55 responden dengan strategi yang kuat sebanyak $29,1 \%$. Hasil analisis ini juga didapatkan $p$ value 0,025 ( $p$ value $<0,05$ ), ada hubungan yang bermakna antara strategi kompetisi dengan kepuasan kerja.
Tabel 7. Hubungan strategi Akomodasi dengan Kepuasan Kerja

\begin{tabular}{lccccccc}
\hline \multirow{2}{*}{$\begin{array}{l}\text { Akom } \\
\text { odasi }\end{array}$} & \multicolumn{5}{c}{ Kepuasan Kerja Perawat } & \multirow{2}{*}{$\begin{array}{c}\text { P } \\
\text { Pelaksana }\end{array}$} \\
\cline { 2 - 6 } & $\begin{array}{c}\text { Kurang } \\
\text { Puas }\end{array}$ & \multicolumn{4}{c}{ Puas } & $\begin{array}{c}\text { Tot } \\
\text { al }\end{array}$ & \\
\cline { 2 - 7 } & $f$ & $\%$ & $f$ & $\%$ & $f$ & $\%$ & \\
\hline Lemah & 24 & 60 & 16 & 40 & 40 & 100 & \\
Kuat & 8 & 18,6 & 35 & 81,4 & 43 & 100 & 0,000 \\
\hline Jumlah & 32 & 38,6 & 51 & 61,4 & 83 & 100 & \\
\hline
\end{tabular}

Berdasarkan tabel di atas didapatkan bahwa dari 40 responden yang memiliki strategi akomodasi lemah dengan kepuasan kerja yang kurang puas sebanyak $60,0 \%$. Sedangkan dari 43 responden dengan strategi yang kuat sebanyak $18,6 \%$. Hasil analisis ini juga didapatkan $\mathrm{p}$ value 0,000 ( $\mathrm{p}$ value $<0,05$ ), ada hubungan yang bermakna antara strategi akomodasi dengan kepuasan kerja

Tabel 8. Hubungan Strategi Menghindar dengan Kepuasan Kerja

\begin{tabular}{lccccccc}
\hline \multirow{2}{*}{$\begin{array}{c}\text { Strategi } \\
\text { Menghi } \\
\text { ndar }\end{array}$} & \multicolumn{4}{c}{ Kepuasan Kerja Perawat } & \multirow{3}{*}{$\begin{array}{l}\text { P } \\
\text { Pelaksana }\end{array}$} \\
\cline { 2 - 6 } & $\begin{array}{c}\text { Kurang } \\
\text { Puas }\end{array}$ & \multicolumn{2}{c}{ Puas } & Total & \\
\cline { 2 - 6 } & $f$ & $\%$ & $f$ & $\%$ & $f$ & $\%$ & \\
\hline Lemah & 15 & 60,0 & 10 & 40,0 & 25 & 100 & \\
Kuat & & 29,3 & 41 & 70,7 & 58 & 100 & 0,017 \\
& 17 & & & & & & \\
\hline Jumlah & 32 & 38,6 & 51 & 61,4 & 83 & 100 & \\
\hline
\end{tabular}

Berdasarkan tabel di atas didapatkan bahwa dari 25 responden yang memiliki strategi menghindar lemah dengan kepuasan kerja yang kurang puas sebanyak $60,0 \%$. Sedangkan dari 58 responden dengan strategi yang kuat sebanyak 29,3\%. Hasil analisis ini juga didapatkan $p$ value 0,017 ( $p$ value $<0,05$ ), ada hubungan yang bermakna antara strategi menghindar dengan kepuasan kerja. 
Tabel 9. Hubungan Strategi Kolaborasi dengan Kepuasan Kerja

\begin{tabular}{|c|c|c|c|c|c|c|c|}
\hline \multirow{3}{*}{$\begin{array}{c}\text { Strategi } \\
\text { Kolabor } \\
\text { asi }\end{array}$} & \multicolumn{6}{|c|}{$\begin{array}{c}\text { Kepuasan Kerja Perawat } \\
\text { Pelaksana }\end{array}$} & \multirow[t]{3}{*}{$\begin{array}{l}\mathrm{P} \\
\text { value }\end{array}$} \\
\hline & \multicolumn{2}{|c|}{$\begin{array}{l}\text { Kurang } \\
\text { Puas }\end{array}$} & \multicolumn{2}{|c|}{ Puas } & \multicolumn{2}{|c|}{ Total } & \\
\hline & $F$ & $\%$ & $f$ & $\%$ & $f$ & $\%$ & \\
\hline Lemah & 17 & 56,7 & 13 & 43,3 & 30 & 100 & \\
\hline Kuat & 15 & 28,3 & 38 & 71,7 & 53 & 100 & $0,0<1$ \\
\hline Jumlah & 32 & 38,6 & 51 & 61,4 & 83 & 100 & \\
\hline
\end{tabular}

didapatkan bahwa dari 30 responden yang memiliki strategi kolaborasi lemah dengan kepuasan kerja yang kurang puas sebanyak 17(56,7\%). Sedangkan dari 53 responden dengan strategi yang kuat sebanyak $28,3 \%$. Hasil analisis ini juga didapatkan $\mathrm{p}$ value 0,021 ( $\mathrm{p}$ value $<0,05$ ), ada hubungan yang bermakna antara strategi kolaborasi dengan kepuasan kerja

\section{PEMBAHASAN}

Berdasarkan hasil penelitian terdapat hubungan antara kemampuan manajemen konflik kepala ruangan dengan kepuasan kerja perawat pelaksana, dimana semakin kuat atau baik manajemen konflik yang digunakan kepala ruangan akan semakin baik pula tingkat kepuasan yang dirasakan perawat pelaksana dalam bekerja.

Berdasarkan hasil penelitian hubungan strategi kompromi dengan kepuasan kerja didapatkan hasil $P$-value pada chi-square sebesar 0.017, berada jauh dibawah tingkat kesalahan 0,05. Hasil $(0,017<$ $0,05)$ artinnya terdapat hubungan yang bermakna antara strategi kompromi dengan kepuasan kerja perawat di RST Tk. III Reksodiwiryo Padang.

Temuan penelitian ini didukung oleh penelitian yang dilakukan oleh Daniyanti (2016) didapatkan hasil bahwa ada hubungan manajemen konflik dengan kepuasan kerja $(p$-value $=0,032)$. Dari 40 perawat yang manajemen konfliknya baik, $(55,0 \%)$ perawat merasa puas dengan pekerjaannya. Sedangkan dari 33 perawat yang manajemen konfliknya kurang baik, $(72,3 \%)$ perawat merasa kurang puas dengan pekerjaannya. Sehingga dapat disimpulkan bahwa manajemen konflik strategi kompromi memberikan pengaruh yang signifikan terhadap kepuasan kerja perawat.

Dari hasil penelitian ini juga menunjukkan hasil ada hubungan antara strategi kompetisi yang lemah dengan kepuasan kerja perawat yang kurang puas.

Dan Dari hasil penelitian ini juga menunjukkan hubungan antara strategi akomodasi dengan kepuasan kerja dimana manajer dengan strategi akomodasi yang lemah akan berpengaruh terhadap kepuasan kerja

Berdasarkan analisis diatas peneliti berasumsi bahwa konflik akan mudah ditangani ketika manajer konflik dapat mengakomodir kepentingan bersama. Manajer yang baik melakukan hal-hal manajerial secara efektif dan efisisen dengan pengarahan yang dilakukan ke bawahannya terkait dengan manjemen konflik khususnya dengan pendekatan akomodasi sehingga hasil yang harapkan perawat merasa puas dalam melakukan pekerjaannya di ruangan.

Hasil penelitian ini menunjukkan adanya hubungan antara strategi menghindar dengan kepuasan kerja yang kurang puas yaitu sebanyak 60,0\%. Penelitian ini juga sejalan dengan penelitian Rahim, dalam sebuah Jurnal Didit Raditya (2013), bahwa strategi manajemen konflik ini diasosiasikan dengan penarikan diri, menghindar dari masalah, menghindar ini ada dua makasud, pertama untuk menunda hingga waktunya 
tepat, atau menghindar karena tidak nyaman bagi dirinya.

Strategi kolaborasi yang lemah membuat kepuasan kerja yang kurang puas hal ini sejalan dengan penelitian Kilmann dan Thomas dalam Millia (2012) dalam penelitiannya yang mengkorelasikan tipe kepribadian dan gaya manajemen konflik menghasilkan kesimpulan bahwa individu dengan tipe kepribadian ekstrovert cenderung menyukai gaya manajemen konflik kolaborasi dan kompetisi.

\section{KESIMPULAN}

Berdasarkan hasil analisis data dan pembahasan yang telah disampaikan peneliti dapat menyimpulkan bahwa hampir setengah perawat pelaksanaan menilai kurang puas terhadap kepuasan kerja perawat pelaksana di Ruang Inap Rumah Sakit Tk III Dr. Reksodiwiryo Padang, dan perawat menilai lemahnya kemampuan manajemen konflik secara keseluruhan yang dilakukan oleh kepala ruangan, termasuk juga untuk strategi akomodasi, strategi menghindar, strategi kolaborasi yang mempengaruhi kepuasan kerja perawat pelaksana di Ruang Inap Rumah Sakit Tk III Dr. Reksodiwiryo Padang.

Terdapat hubungan yang sangat signifikan antara kemampuan manajemen konflik, strategikompromi, strategi kompetisi, strategi kolaborasi, strategi akomodasi dan strategi menghindar terhadap kepuasan kerja perawat pelaksana di Ruang Inap Rumah Sakit Tk III Dr. Reksodiwiryo Padang.

\section{DAFTAR PUSTAKA}

Daniyanti, Marya .(2016). Hubungan Manajemen Konflik Dengan Kepuasan Kerja perawat pelaksana di Ruang Rawat Inap Kelas III Rumah Sakit Umum Daerah Dr. Zainoel Abidin Banda Aceh.

Hamdan, Dkk (2015) Gaya Manajemen Konflik Pada Perawat Manajer Di Jordania Dan Hubungan Dengan Keinginan Perawat Pelaksana Untuk Tetap Tinggal.

Khayati MN, dkk. (2015). The impact of training on the management of children with cough of the health workers' knowledge, attitude and skills in the management of children with cough and breathing difficulties. International Journal of Research in Medical Sciences.Khayati FN et al. Int J Res Med Sci. 2015 Dec;3(Suppl 1):S47- S52

Nursalam. (2016). Metodologi Penelitian Ilmu Keperawatan. Jakarta: Selemba Medika.

Rachman, D.A., Hamzah. A., \& Jafar. N. (2013). Pengaruh perilaku kelompok terhadap kepuasan kerja perawat di RSUD Syekh Yusuf Kabupaten Gowa. FakultaskesehatanmasyarakatUni versitasHasanuddin.Retrievedfro mhttp://pasca.unhas.ac.id/jurnal/fi les/72c771deb6b54236d45fac48fc 0e4456. pdf

Raditiya, didit. (2012). Analisis pengaruh manajemen konflik dan kepuasan 
NERS: Jurnal Keperawatan, Volume 15, No. 2, Oktober 2019, (Hal. 155-162)

kerja pada direktorat jendeal perkebunan kementerian pertanian RI. FE UI.

Soemarman, T, 2013. Conflict Management dan Capacity Building for Profesional Development. Mengelola Konflik untuk Memaksimalkan Produktivitas Kinerja dan Pengembangan Profesionalisme. PT. Elex Media Komputindo, Jakarta. 